\title{
ФОРМУВАННЯ ЧИТАЦЬКОЇ КУЛЬТУРИ МОЛОДШИХ ШКОЛЯРІВ ЯК АКТУАЛЬНА ПРОБЛЕМА СЬОГОДЕННЯ
}

intellectual capital of Poland]. Warsaw, 154 p. [in Polish].

2. Marat, E. (2014). Rodzina $z$ dzieckem niepetnosprawnym. W ks. Janicka I, Liberska H. Psychologia rodziny [Family with a disabled child. At father Janichka I, Liberska H. Family psychology]. Warsaw, 682 p. [in Polish].

3. Ministerstwo Edukacji Narodowej: www.gov.pl/web/ edukacja [Ministry of Education]. Available at: www.gov.pl / web/ edukacja [in Polish].
4. Szempruch, J. (2000). Pedagogiczne kształcenie nauczycieli wobec reformy edukacji w Polsce [Pedagogical education of teachers in the context of reform of education in Poland]. Rzeszów: Publishing House of the University of Pedagogy, 378 p. [in Polish].

5. Szmidt, K. J. (2003). Dydaktyka twórczości [Didactics of creativity]. Krakow: Impuls, 378 p. [in Polish].

6. Szmidt,K. J. (2013). Pedagogika twórczości [Pedagogy of creativity]. Sopot: Gdańsk Psychological Publishing House, 737 p. [in Polish].

Стаття надійшла до редакції 03.06.2020

УДК 373.01:37:004(082)

DOI:

Галина Білавич, доктор педагогічних наук, професор кафедри педагогіки початкової освіти, ДВНЗ “Прикарпатський національний університет імені Василя Стефаника" Мар'яна Шетеля, студентка другого (магістерського) рівня освіти кафедри педагогіки початкової освіти,

ДВНЗ “Прикарпатський національний університет імені Василя Стефаника”

\section{ФОРМУВАННЯ ЧИТАЦЬКОЇ КУЛЬТУРИ МОЛОДШИХ ШКОЛЯРІВ ЯК АКТУАЛЬНА ПРОБЛЕМА СЬОГОДЕННЯ}

Стаття присвячена актуальній педагогічній проблемі сьогодення - формуванню інтересу до читання зростаючої особистості. Розглянуто стан читацької культури молодших школярів, з 'ясовано, щзо художсня література з різних причин втрачає свою роль серед учнівства. Проаналізовано показники, які змущують задуматися над проблемами формування культури читання молодших школярів, та означено способами їх розв'язання.

Ключові слова: читацька культура; молодші школярі; художня література; читання; інтерес до читання.

Jim. 5.

Halyna Bilavych, Doctor of Sciences (Pedagogy), Professor of the Pedagogy of Primary Education Department, Vasyl Stefanyk Precarpathian National University

Maryana Shetelya, Student of the Second (Master's) Level of Education of the Pedagogy of Primary Education Department, Vasyl Stefanyk Precarpathian National University

\section{FORMATION OF READING CULTURE AMONG JUNIOR SCHOOLCHILDREN AS A CURRENT PROBLEM OF TODAY}

The article is devoted to the formation of reading culture among junior schoolchildren as a current problem of today. Reading is one of the most popular activities. In the modern society reading skills are an integral part of the formation and development of a person, his or her learning and professional career. Reading is a complex phenomenon. It is a principle factor that ensures obtaining of general education, the main means of acquiring knowledge in higher education institutions. Reading plays an extremely important role for a competent personality development. It is not only a social phenomenon (helping to develop an individual as a personality, contributing to the formation of emotional culture, intelligence, logical and creative thinking), but also a pedagogical phenomenon, which is an important factor in the education of spirituality, aesthetic feelings, creators, rhetorical skills, and other personal qualities. It is known that the more a person reads, the greater general cultural experience and the higher level of intellectual development they have, the more expressive their speech becomes.

The degree of involvement of boys and girls into reading shows the level of humanization of the entire society, that is why our research is focused on junior schoolchildren, as these people will soon be teaching and educating younger students as active readers. It is they who can lead early and sustained interest in reading to students, a kind of navigator in the overall flow of reading products for both children and their parents.

In the primary school, the range of reading interests of the youth narrows; great spiritual potential of fiction remains out of the sight for most children. Such indicators make one think about the problems of forming the reading culture of juniors and the means of solving them. Therefore, it is necessary to raise the level of education, in particular literary, since it is the young educated people with critical thinking, forming the demand for a book, can 


\section{ФОРМУВАННЯ ЧИТАЦЬКОЇ КУЛЬТУРИ МОЛОДШИХ ШКОЛЯРІВ ЯК АКТУАЛЬНА ПРОБЛЕМА СЬОГОДЕННЯ}

dictate the mode of reading. At the state level, it is necessary to begin with the creation of a literary map of his area, to begin studying the literary process of each region in the state and every ethnos that populate Ukraine, to start work on investigating the historical and cultural heritage, the creative achievements of local writers in different historical periods.

Keywords: reading culture; young students; fiction; reading; an interest in reading.

$\Pi$ остановка проблеми. Читання належить до одного з поширених видів діяльності, воно є невід'ємним елементом становлення та розвитку особистості, іiі навчання, професійної кар'єри.

Сьогодні молодші школярі $є$ активними споживачами інформаційних ресурсів $i$, як наслідок, - однією із пріоритетних читацьких груп, що перебуває в центрі уваги багатьох учених. Відтак ступінь інтересу учнів до читання певною мірою прогнозує і рівень гуманізації всього суспільства, тому важливо виховати молодших школярів як активних читачів. Саме в цьому віці треба створити такі умови, які забезпечать формування раннього і стійкого інтересу до читання у школярів, які в подальшому будуть активними читачами та своєрідними навігаторами в загальному потоці читацької продукції.

Важливо також пам'ятати: навички читання та читацька компетентність є основою успішного шкільного навчання, а відтак і професійної кар'єри, популяризація читання - одна 3 найефективніших умов розвитку духовності підростаючого покоління.

Мета статті - проаналізувати стан читацької культури молодших школярів.

Виклад основного матеріалу. Ситуація в Україні з дитячим читанням $є$ доволі складною. По-перше, зростають нові покоління потенційних функціональних неграмотних осіб з-поміж дітей та підлітків, про що засвідчують результати зовнішнього незалежного оцінювання, які щороку 3 базових предметів, зокрема й з української мови та літератури, є нижчими.

По-друге, через брак навичок читання випускники не мають достатніх передумов, підстав для університетської освіти та доступу до ринку праці. Можна спрогнозувати, що надалі ситуація ускладниться, а в наступних поколіннях стане критичною, якщо держава, громадські товариства, батьки серйозно не замисляться над проблемою формування читацької культури дітей, адже сьогоднішні юнаки та дівчата самі через декілька років матимуть дітей та не зможуть надати їм необхідної підтримки як батьки $[3,103]$.

По-третє, інтерес до читання в дітей та юнацтва знижується, що з-поміж іншого спричинено і тим фактом, що доросле населення зрідка звертається до книжки. До прикладу, за результатами соціологічного опитування компанії
Research \& Branding Group, 57 \% українців не читає книг. Найчастіше читає молодь від 18 до 30 років. Також люди цієї вікової категорії часто ходять на концерти $-26 \%$ або в театри $-13 \%$. $60 \%$ дорослих за останній рік не читали жодної книжки та близько $50 \%$ не відвідали жодної культурної події протягом року. 3-поміж перепон для цього вони вважають брак часу та грошей [2].

Оприлюднені 2019 року результати міжнародного дослідження PISA, участь у якому Украӥна вперше взяла 2018 року, теж бажали б бути ліпшими: показники українських учнів є трохи нижчими за середні показники учнів країн (OECP). Ідеться про сформованість читацької, математичної та компетентності у природничих науках. Середній бал українських учнів із читання (компетентність із читання) - 466 балів (у країнилідера -555 , у середньому в країнах OECD - 487). На такому ж рівні (466 балів) перебувають і Білорусь, Ізраїль, Туреччина, Словацька Республіка, Люксембург, Греція. За результатами дослідження PISA, 70,7% українських школярів досягли другого четвертого рівнів сформованості читацької компетентності (у країнах OECD - 77\%). Водночас 25,9\% українських 15-річних учнів не мають базового рівня в читанні (у країнах ОЕСD $-23 \%$ ). Водночас $5-6$-го рівня досягнули лише $3,4 \%$ (у країнах OECD - 9 \%). Отже, за висновком PISA, на цих рівнях юнаки та дівчата можуть формувати “повне і детальне розуміння тексту 3 незнайомим змістом чи формою, а також розбиратися 3 поняттями, які суперечать очікуванням" [4].

По-четверте, зарезультатами загальнонаціонального репрезентативного дослідження читацьких звичок та ставлення до читання, проведеного на межі 2013 - 2014 pp. експертами pro.mova разом із партнером та замовником дослідження ГО “Форум видавців” у межах проекту Book Platform, виявлено таку тенденцію в розвитку однієї 3 важливих форм культурної практики сучасних українців - читанні, як поверхневе, неглибинне читання, що засвідчує про відсутність цілісності читання, вдумливого читання, взаємодії читача 3 текстом, отже, у таких осіб мало розвинена навичка глибокого читання. 3 огляду на те, що вдумливе читання характеризується здатністю 


\section{ФОРМУВАННЯ ЧИТАЦЬКОЇ КУЛЬТУРИ МОЛОДШИХ ШКОЛЯРІВ ЯК АКТУАЛЬНА ПРОБЛЕМА СЬОГОДЕННЯ}

знаходити для нього спеціальний час, отримувати задоволення від читання, читати великі тексти від початку до кінця, концентруватися на читанні, прагнути обговорювати прочитане, міркувати над прочитаним і повертатися до нього, соціологи виокремили групи читачів за індексом розвитку читацької навички.

Так, найбільшою $(56,1$ \%) виявилася група читачів, які продемонстрували середній рівень розвитку читацької навички. Група з високим рівнем їі розвитку на другому місці (37,6 \%). Однак разом вони формують переконливу більшість - близько 90 \%. Середньостатистичному українцеві читання приносить задоволення, він перечитує, обдумує й обговорює прочитане 3 іншими. Авторитетна дослідниця Е. Огар зазначає: "За описаними вище відмінностями у способі читання, а саме за шириною (охоплення усієї палітри запропонованих у питальнику текстів), щоденною систематичністю читання, тривалістю не менше ніж дві години в один сеанс читання, цілісністю, інтенсивністю “взаємодії” з текстом соціологи виокремили чотири групи читачів 3 різним характером читацької поведінки. Найчисельнішою (40,2 \%) виявилася четверта 3 виокремлених група - “всеїдні читачі” 3 найвищим індексом ширини читання. Як на мене, не дивно, що в їхній читацькій поведінці цілісне читання поєднується із фрагментарним: різні типи текстів вимагають різних способів осягнення" [1].

Наразі склалася певна суперечність: при несистематичному і нетривалому читанні зберігається високий показник вдумливості. На другому місці (29,4 \%) опинилася перша 3 виокремлених груп - перебірливі читачі 3 найбільш розвиненою читацькою навичкою (вдумливе, глибоке читання). Читацька поведінка цієї групи є логічно вмотивованою і зрозумілою: іiі представники читають цілеспрямовано, вдумливо та систематично і при цьому підходять до вибору текстів критично.

Наведемо окремі результати дослідження читацької активності молодших школярів (62 учнів четвертого класу). За результатами опитування було встановлено частоту читання художньої літератури: шестеро дітей читають художню літературу (поза навчальною програмою) щодня; 18 четвертокласників - кілька разів на тиждень; 21 респондент - кілька разів на місяць; 18 осіб кілька разів за 3 - 4 місяці; четверо дітей - кілька разів на півроку; один учень - кілька разів на рік і рідше.

Декілька разів на тиждень відвідують бібліотеки 8 осіб; кілька разів на місяць - 14 осіб; кілька разів на 3 - 4 місяці - 27 четвертокласників; кілька разів на півроку - 8 осіб; кілька разів на рік і рідше - 3 осіб, двоє учнів узагалі не відвідують бібліотеки.

Цікавими виявилися відповіді молодших школярів на запитання "Хто впливає на вибір книги для читання?” Деякі респонденти вважають, що не впливає ніхто (відповіді “ніхто”, “сам/сама”). 3 одного боку, це може свідчити про сформований у дитини читацький запит та інтерес до книги. 3 іншого - якщо враховувати сумнівне знання літературних жанрів у десятків респондентів, погане орієнтування в колі читання, можна говорити про відсутність належної рефлексії. 3поміж ключових чинників впливу на вибір кола читання названі: учителька (48 згадувань), друзі (6 згадувань), батьки (6 згадувань), реклама у 3MI (2).

Щодо жанрово-тематичних уподобань молодших школярів, то тут думки розділилися приблизно порівну. Значна частина юних респондентів віддають перевагу пригодницькій літературі (31 \%), “твори на шкільну тематику” вибрали 26 \%, 19 \% опитуваних люблять фантастику, 20 \% книголюбів можуть читати літературу найрізноманітніших жанрів, 3 \% дітей відповіли, що “над цим не задумувалися".

Дещо тривожними є результати відповідей молодших школярів на запитання про те, чим люблять займатися у вільний час. Так, 42 дівчаток та хлопчиків проводять час за комп'ютером та телефоном (ігри, листування 3 друзями, підготовка навчальних завдань і т. д.); 10 четвертокласників дивляться телепередачі, відеофільми; 6 осіб займаються спортом; стільки ж - читають художню літературу; 4 молодших школярів гуляють 3 друзями. Як бачимо, книга істотно поступається місцем комп'ютерним іграм, телефонним розвагам.

Беручи до уваги показники “любов до читання”, “проведення вільного часу” (а саме читання художньої літератури), “відвідування бібліотеки" (а саме кількість учнів, які зрідка відвідують бібліотеку та не відвідують іiі) молодших школярів, можна констатувати той факт, що ці показники є недостатніми для того, щоб стверджувати про високий рівень формування читацької культури молодших школярів. Очевидною причиною такого становища $\epsilon$ конкуренція книзі з боку медійної культури, народженої телебаченням та інтернетом. За таких умов варто мобілізувати зусилля педагогів, громадськості, батьків, державних структур на активну діяльність, спрямовану на пропаганду читання 3-поміж дітей та юнацтва, а також дорослих. 
Прикладом тут може слугувати Федеративна Республіка Німеччина (ФРН), де, окрім цільової державної підтримки читання, активно діє Фонд читання, метою якого $\epsilon$ “збудити задоволення від читання та посилити навички читання по всій Німеччині - незалежно від матеріальних, культурних чи соціальних потреб кожної людини". У ФРН діє активна пропаганда читання саме 3поміж дітей молодшого шкільного віку, привабливим є такий метод активізації читання, як читання вголос для всіх соціальних груп. 3 огляду на популяризацію читання та соціалізацію читання в сім'ях, закладах освіти та суспільстві, Фонд читання здійснює такі заходи: активізує програми підтримки читання в ранньому дитинстві - "Початок читання", пропонує читання та забезпечує матеріалами для читання сім'ї, батьків та дітей; пропонує послуги цифрового читання за підтримки Фонду Deutsche Bahn, що охоплюють сім’ї з дітьми тощо [5].

На увагу та схвалення заслуговує політика сприяння ранньому інтенсивному читанню (програма "Читання вголос", мережа “Читання вголос" Фонду “Читання"), яка мотивує й активізує волонтерів для пропаганди читання (відомі у ФРН люди: політики, спортсмени, актори, науковці, письменники, митці, громадські діячі, педагоги). Ці та інші заходи забезпечили раннє та інтенсивне сприяння літературно-мовному розвитку, належному рівню читацької компетентності німецьких школярів, сформованим навичкам читання вголос, отримання задоволення від читання, мотивацію до читання та здобуті освітні компетенції. Формальна та неформальна підтримка читання (окрім іншого, клуби читання, пропаганда в ЗМІ, читання як дозвілля, використання читацьких скаутів, які створені у всіх школах та позашкільних навчальних майданчиках) забезпечила те, що в німецьких школярів середній бал із читання (компетентність із читання) - 498 балів (у країни-лідера - 555 балів) [4, 296; 5].

Висновки та перспективи подальших досліджень. Отже, художня книга в силу різних причин втрачає виховну роль 3-поміж молодших школярів, великий духовний потенціал художньої літератури залишається поза увагою певної частини учнів. Це змушує замислитися над проблемами формування читацької культури учнів молодшого шкільного віку, засобами їх розв'язання. На нашу думку, розв'язання цих проблем можна досягти за таких умов: а) знання учнями творчості сучасних дитячих письменників; б) оновлення змісту та структури уроків читання та позакласного читання шляхом вивчення сучасних дитячих бестселерів; в) упровадження в позакласну роботу зі школярами популярної дитячої книжки; г) створення “читацького середовища" в системі сім'я - школа - бібліотека; г) глибокого знання творчості популярних дитячих письменників самим учителем. Предметом подальших досліджень $є$ аналіз засобів і форм виховання інтересу до читання у молодших школярів.

\section{ЛІТЕРАТУРА}

1. Огар Е. Читання в сучасній Україні: припущення, факти, прогнози. URL:http:// www.bookplatform.org/uk/activities/275-readershipukr.html (дата звернення : 12.06.2020)

2. Українці не читають книг. URL: https:// s o c p orta 1.info/2020/01/04/ 57 ukrajintsiv ne chitaje knig.html (дата звернення : 12.06.2020)

3. Bilavych G., Rozman I. Modern fiction as factor of students' reading culture development. Advanced education. 2016. Issue 6. P. 101-105.

4. OECD (2019), PISA 2018 Results (Volume I): What Students Knew and Can Do, PISA, OECD Publishing, Paris. p.298. URL: https://doi.org/10.1787/ 5f07c754-en (дата звернення : 12.06.2020)

5. Stiftung lesen. URL: https://www.stiftunglesen.de/ aktionen/prominente-lesebotschafter/69/\#detail (дата звернення : 12.06.2020).

\section{REFERENCES}

1. Ogar, E. Reading in modern Ukraine: assumptions, facts, forecasts. Available at: http:// www.bookplatform.org/uk/activities/275-readershipukr.html (Accessed 12 June 2020) [in Ukrainian].

2. Ukrainians do not read books. Available at: https://socportal.info/2020/01/04/ 57 ukrajintsiv_ne_chitaje_knig.html (In Ukrainian) (Accessed 12 June 2020) [in Ukrainian].

3. Bilavych, G., \& Rozman, I. (2016). Modern fiction as factor of students' reading culture development. Advanced education, Issue 6, pp.101105. [in English].

4. OECD (2019). PISA 2018 Results (Volume I): What Students Know and Can Do, PISA, OECD Publishing, Paris. Available at: https://doi.org/10.1787/ 5f07c754-en. (Accessed 12 June 2020) [in English].

5. Stiftung Lesen Available at: https:// www.stiftunglesen.de/aktionen/prominentelesebotschafter/69/\#detail (Accessed 12 June 2020). [in English].

Стаття надійшла до редакції 18.06.2020 